\title{
Recovery of Treated Sludge
}

\author{
CARMEN OTILIA RUSANESCU1, MARIN RUSANESCU2*, COSMIN JINESCU3* ION DURBACA ${ }^{3}$ \\ ${ }^{1}$ Politehnica University of Bucharest, Faculty of Engineering of Biotechnical Systems, Romania, 313 Splaiul Independentei, \\ 060042, Bucharest, Romania \\ 2 Valplast Industrie, 9 Preciziei Blvd., 062202, Bucharest, Romania \\ ${ }^{3}$ Politehnica University of Bucharest, Faculty of Mechanical Engineering, 313 Splaiul Independentei , 060042, Bucharest, Romania
}

This paper presents the methods for recovery of treated sludge: technological valorisation, agricultural valorization, energy recovery, gasification, pyrolysis, supercritical oxidation of water, obtaining the material for plastering, obtaining bricks. These technologies are biology-based technologies (advanced anaerobic digestion strategies and bio-drying) and heat-based technologies (gasification, pyrolysis and supercritical water processing).

Keywords: treated sludge, agricultural recovery, energy recovery

The sludge from sewage treatment plants is in category 19 of the waste code, according to the waste classification of Decision no. 856 of 16 August 2002 [1].

Increasing the amount of sludge represents a danger to the environment: water (underground by infiltration and leakage), air (aerobic fermentation by gas release), soil (infestation through uncontrolled storage). The amount of wastewater from the treatment process will increase, causing increased amounts of sludge processed and increased energy consumption specific to sewage treatment and sewage treatment [23].

The recovery and re-use of waste resulting from the treatment of wastewater from industrial processes eliminates the negative impact on the environment and human health $[5,9,13,15-17,3,24-27]$.

\section{Experimental part}

Materials and methods

The sludge from urban waste water treatment plants (Figure 1 ) is considered biodegradable municipal waste [2].

Sludges are the final stage of water treatment, containing raw materials, intermediate products and finished products of industrial activity $[4,9]$. The types of sludge from waste water treatment are: primary sludge resulting from mechanical treatment; secondary sludge resulting from the biological treatment step; mixed sludge resulting from the primary sludge mixture and after the secondary decantation obtained by introducing the excess sludge into the mechanical treatment stage; precipitation sludge resulting from the physico-chemical treatment of water by the addition of neutralizing, precipitation, coagulation-flocculating agents. After the processing stage the sludges can be: stabilized sludge (aerobic or anaerobic); dehydrated sludge (natural or artificial); sanitized sludge (by pasteurization, chemical treatment or composting); fixed sludge resulting from solidification in order to immobilize toxic compounds; ash resulting from the incineration of sludge.

Depending on the composition, the sludge may be: with a predominantly organic composition, containing more than $50 \%$ volatile substances in the dry matter resulting from the mechanical-biological purification; sludges with a predominantly inorganic composition containing more than $50 \%$ of the dry matter resulting from the physicochemical treatment.

The solid materials to be removed from wastewater treatment are as follows: retaining on slats, solids, generally dehydrated and compacted; sand - coming from scrapers, sometimes separated from organic matter; Primary sludge - sedimentary solids resulting from primary decantation; secondary sludge (excess) - suspended solids incorporated into sludge and biomass flocs resulting from the dissolution of pollutant organic matter; fats and oils floating substances; nutrients - nitrogen and phosphorus reduced after the biological treatment and chemical precipitation process. Sludge processing processes are multiple and varied, depending on their provenance and characteristics, but also on the final mode of disposal.

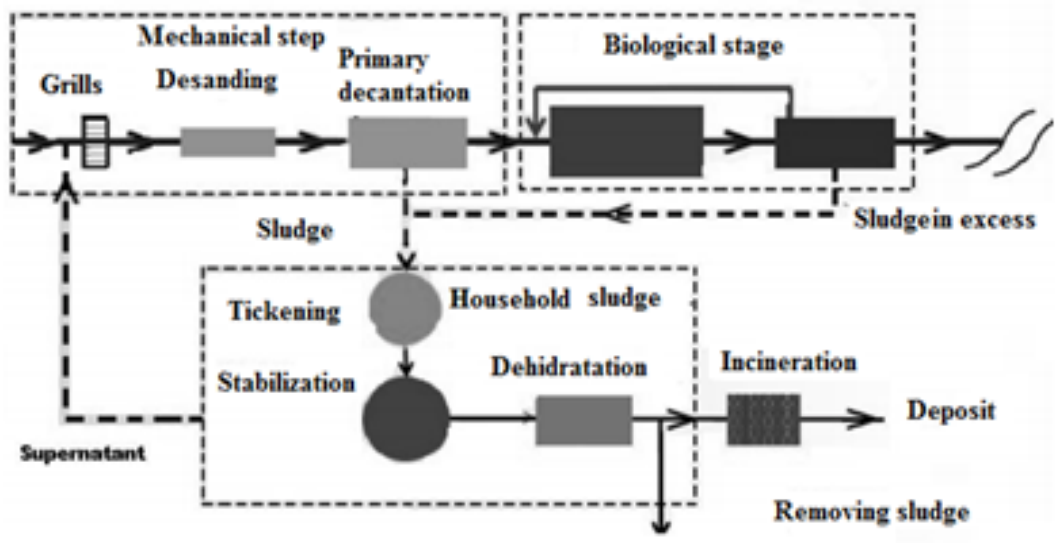

Fig. 1 Scheme of a sewage treatment plant [2]

Sludge used in agriculture

* email: rusanescu@yahoo.com; cosmin.jinescu@yahoo.com 


\section{Results and discussions}

Classification of processing can be done according to the following criteria: humidity reduction, mineralization of the organic component, etc. [2].

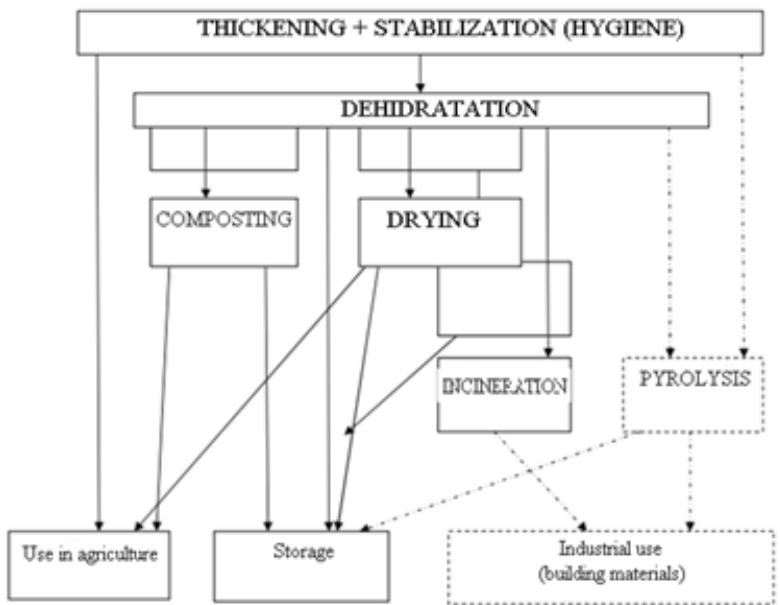

Fig. 2 Sludge treatment processes [2]

For sludge reuse and recycling, the amount of sludge has to be reduced by: purification treatment interventions using innovative technologies, reduction of sludge by oxidation (chemical or thermal processes) [6].

Waste-sludge treatment methods in Romania [6]:

- Thickness for water removal is achieved by: sedimentation, flotation, filtration, centrifugation: in order to reduce the volume, the efficiency of the homogenization;

- Stabilization by anaerobic fermentation, aerobic stabilization for volume reduction and pathogen reduction, production of fermentation gas;

- Chemical and thermal conditioning to increase solids uptake, improve filtration, modify structure;

- Disinfection by irradiation, pasteurization, composting, lime and chlorine treatmentto ensure the recovery of sludge in agriculture and forestry, the elimination of pathogens;

- Dehydration with drying platforms, centrifugal filters, press filters and vacuum filters for water removal, reduction of transport and energy costs;

- Drying with rotary dryer, belt, flatbed and atomizer for water removal, sterilization of the material;

- Combustion burning, wet oxidation and pyrolysis for total destruction of organic matter, total water removal, sterilization and modification of the material content;

- Final disposal through agricultural fertilization, restoration of degraded land, construction materials, amendment, land storage, underground storage for total removal, reintegration in the circuit, recovery [6].

The sludge from sewage treatment plants has a high water content of up to $97 \%$, which can be reduced by 70 $80 \%$ by centrifugation, which is a condition for both transport and storage or disposal $[6,7]$.

\section{Technological use}

Sludge from treatment and treatment plants can be used in construction combined with raw material, thus reducing energy consumption and producing a material that responds to circular economy solutions. Heavy metals in the sludge content are recovered by galvanic coatings containing significant quantities of hydroxides (chromium, nickel, zinc, copper, etc.) [8].

\section{Agricultural exploitation}

Sludge from sewage treatment plants can be used in forestry, rehabilitation of degraded land and agricultural land.
Purified sludges are used to apply them to agricultural land, composting and then using compost from sewage sludge as a fertilizer for horticultural crops or as a source of organic matter and nutrients for agricultural land [12].

Purified sludge contains nutrients (N, K, P), which are important when using sludge as agricultural fertilizer or as soil conditioner. Agricultural use of sludge is conditioned by the presence and the amount of heavy metals with a high degree of toxicity [14].

Liquid sludge contains the following elements: Nitrogen $(3.5-6.4 \%)$, Phosphate $(1.8-8.9 \%)$, Potassium (0.24 $0.48 \%$ )

Because the sludge generated from the biological treatment stage of the treatment plants is to be used in agriculture, the heavy metals should have the maximum admissible concentration ( $\mathrm{mg} / \mathrm{kg}$ of dry matter) as follows: (Cadmium - 10, Copper - 500, Nickel - 100, Lead - 5; Chrome - 500; Cobalt - 50, Arsen - 10) [26].

The sludge sludge can be used in agriculture only if the legal provisions of the Joint Order of the Ministry of Environment and Waters and the Ministry of Agriculture no. 344/2004 for the approval of technical norms regarding the protection of the environment and especially of the soil when the sludge is used in agriculture.

Sewage sludge has $97 \%$ water content. By centrifugation or filtration the water content can be reduced to $70-80 \%$, for this reason the dehydration process is a prerequisite for economical transport and possible storage / disposal. Agricultural reuse requirements require a drying level of more than $90 \%$ to ensure that the sludge is not fermentable and can be stored in silos until reuse

Table 1 presents the physico-chemical characteristics of sludge from household wastewater treatment [14].

Table 1

THE PHYSICO-CHEMICAL CHARACTERISTICS OF SLUDGE FROM HOUSEHOLD WASTEWATER TREATMENT

\begin{tabular}{|lc|}
\hline Physico-chemical characteristics & Active sludge [\%] \\
\hline Humidity & $95-99$ \\
\hline Mincral matcrials & $25-38$ \\
\hline Orgaric matenals & $62-75$ \\
\hline Fatty subatanccs & $5-12$ \\
\hline Protein & $35-41$ \\
\hline Ammoniacal nitrogen & 17 \\
\hline Phosphates & $3-4$ \\
\hline
\end{tabular}

The calculation of the amount of sludge that can be used in agriculture for 30 years in tonne per hectare is based on the concentration of heavy metals [21-23]:

$$
\mathrm{D}_{\mathrm{n}} 30=\left(0,8 \mathrm{C}_{\max } \mathrm{sol} / \mathrm{C}_{\text {nămol }}\right) * \mathrm{~K}
$$

where: $D_{n 30}$ is the amount of dry sludge in 30 years in [t/ ha]; $C_{\max }{ }^{\text {nis }}$ the permitted metal concentration in the soil $[\mathrm{mg} / \mathrm{kg}]$ of dry matter; $\mathrm{C}_{\text {sludge }}$ is the concentration of metal present in the soil [mg/skg of dry matter]; $K$ is a factor that shows the fertile soil on 1 hectare of agricultural land ( $K=$ 3000).

The amount of sludge used will be based on the type of crop rotation and soil characteristics to avoid the risk of bioaccumulation of pollutants. The total soil porosity is 
increased by the application of lime treated sludge [ 32 , 34].

The amount of accumulated sludge that can be applied over time is calculated according to the concentration of pollutants [33]:

$$
R_{m}=\frac{L_{m}}{C_{m} \cdot 2000}
$$

where: $R_{m}$ - the maximum amount of sludge that can be applied during land use, [tons of dry matter per acre] (one acre $=0.4047 \mathrm{ha}$ ) $; \mathrm{L}_{m}=$ the maximum amount of pollutant that can be applied during land use in accordance with the legislation, [kilograms / acre] (one kilogram $=453.59 \mathrm{~g}$ ); $\mathrm{C}_{\mathrm{m}}=$ percentage of pollutant contained in sludge expressed in decimal (eg 50ppm Cd in sludge $=0.000050$ ); $2000=$ kilograms $/$ tonne of dry matter from sludge ( 2000 $\mathrm{kg}=907 \mathrm{~kg}$ )

The use of sludge in agriculture has the following advantages:

Improving the physical and organic soil properties by the intake of nutrients (nitrogen, phosphorus, sulfur), trace elements, organic compounds; Recover nutrients and reduce the consumption of natural resources. It is the most efficient method of recovering phosphorus from sludge; Improving soil characteristics by increasing water retention capacity, improving humus layer quality or $\mathrm{pH}$ correction; Replacement of chemical fertilizers and reduction of environmental risks associated with their use, including the degradation of agricultural land; Lowering costs due to agricultural land fertilization by replacing chemical fertilizers; Utilization of sewage sludge and reduction of land areas necessary for the storage of waste resulting from human activities and the associated environmental risks; Growth of crop production; Sustainable environmental development with benefits for the sludge producer and the farmer; Water retention in soil; Improving microbial activity in soil; Rehabilitation of degraded lands by improving soil texture; Low cost; Simple technology.

When applying sludge to agricultural land, accountmust be taken of the physical, chemical and biological properties of sludge and soil properties, its capacity for sludge loading, the ability of plants to harvest the nutrients from these organic residues and the danger of environmental pollution.

\section{Energy recovery}

Anaerobic fermentation is an energy recovery process during the sludge treatment process with the purpose of extracting methane $(60-65 \%)$ that generates heat (37-40 ${ }^{\circ} \mathrm{C}$ ) and energy in a short time of about 6 hours. Fermented sludge removed from biogas tanks can be redeemed by: re-use on farmland, co-processing in cement plants, or incineration / co-incineration in installations meeting energy efficiency requirements for energy recovery.

Electricity produced from biogas has a significant impact, solves the environmental problem associated with sewage sludge and obtains economic benefits from the production of fermentation gas [18].

Co-digestion of sewage sludge with non-alloyed organic waste. Anaerobic digestion is applied in domestic water treatment plants to stabilize primary and biological sludge before final disposal, while recovering energy through biogas. All types of energy recovery such as co-incineration in cement plants, combustion, or fluid bed incineration require sufficient calorific power of the sludge. This implies that the drying process takes place in a separate installation or in combination with an incinerator. Generally, the energy required for waste water treatment is 20-30
kWh per equivalent per year, and mixed sludge digestion can produce up to 10-15 kWh per equivalent per year under the best conditions, while co-digestion can contribute to meeting this demand that offers energy independence [19].

Bio-drying of sewage sludge for the production of biomass fuels.

Bio-drying is an efficient energy-saving technology for reducing sludge volume and limited water evaporation through the use of biologically produced heat [20]. Bio-dry sludge has a high energy content that can be used to produce steam and / or combustion power, reducing fossil fuel requirements and positively contributing to climate change prevention. A major benefit of bio-drying is to incorporate the biogenic content of input waste, a source of $\mathrm{CO}_{2}$-neutral energy, into a fuel product [19].

\section{Gasification}

Gasification is a thermo-chemical process in which any carbon-containing material is converted into a combustible gas in the presence of a reactive atmosphere (air, steam or $\mathrm{CO}_{2}$ ) and at a temperature typically ranging from 800 to $900\left[{ }^{\circ} \mathrm{C}\right]$. gasification consists of a mixture of $\mathrm{CO}, \mathrm{CO}_{2}, \mathrm{H}_{2}$, $\mathrm{CH}_{4}$ and other light hydrocarbons, steam and $\mathrm{N}_{n}$ if the air is used as a gasification medium. By gasification technology sewage sludge is managed, waste volume is reduced, toxic organic compounds are removed and heavy metals are fixed in the resulting solid [19].

Gasification of the anaerobic and heat-dried sludge, under air, uses between 20 and $40 \%$ of the oxygen required for total combustion. Gas yields are $1.5-2.5 \mathrm{Nm}^{3} / \mathrm{kg}$ of dry sewage sludge, depending on the physical and chemical properties of the raw materials as well as the type of gasifier $[19,20]$. Sewage sludge can be considered as a renewable energy source suitable for gasifiers for the production of heat while removing such waste [20].

\section{Pyrolysis}

Pyrolysis is a thermochemical reaction performed in an inert atmosphere, usually $\mathrm{N}_{2}$, and at a temperature of about $500^{\circ} \mathrm{C}$. Three products (carbon, liquid and gas) are obtained in the process. Many research projects aim at obtaining the liquid product because it has promising physicochemical properties to be used as a fuel or as a source of valuable chemicals [19].

\section{Supercritical water processing}

As already elucidated, thermochemical processing of sludge has many potential advantages over biologic processing. These include several orders of magnitude faster reactions and generally complete elimination or inactivation of all pathogens, since the processing temperatures exceed $100-150\left[{ }^{\circ} \mathrm{C}\right]$. Thermochemical processes are also quick to start (no need to acclimate or build biomass) and are generally better coping with fluctuations than biological processes.

A promising thermochemical process for sludge treatment and energy recovery is supercritical water processing, especially supercritical water oxidation and supercritical water gasification. Supercritical water oxidation refers to processing in the presence of an oxidant, generally oxygen, supplied to the treated stream either by pure oxygen or by air, and the supercritical gasification process of the water is conducted in the absence of the oxidant [21].

\section{Getting the bricks}

The centrifuged sludge is mixed with: $45 \%$ cement + $55 \%$ sludge. The mixture is homogenized for 15 min until a 
homogeneous paste is poured into metal or wood. Allow to dry for 24 hours, remove from the molds, leave to air for $3-4$ days, to bring in contact with the slurry of $\mathrm{CO}_{2}$ from the air, to increase the resistance [10].

\section{Obtaining plaster material}

The centrifuged sludge is mixed with: $25 \%$ cement + $75 \%$ sludge. Stir the slurry with cement, over which add $20 \%$ water. Homogenize for 15 minutes [10]. These mixtures are freeze dried.

The energy utilization of sludge through incineration in a cogeneration system converts the sludge energy content into thermal and electrical energy, which will later be used to reduce its own energy consumption in wastewater and sludge treatment processes.

Sludge treatmenthas as main object the decomposition of organic matter following biochemical processes (biological processes). The biological processes that occur during the decomposition of organic matter are two categories [4]: aerobic processes, in which organic matter is combined with oxygen (oxidation), with the production total sludge production estimated at the end of 2020 of 415,600 to.su/an, $50 \%$ will be used in agriculture, $20 \%$ will be incinerated and the remaining $30 \%$ will be co-processed in cement plants.

Extreme scenario, which states that from the total amount of sludge of 415600 tsu / year, obtained at the level of 2020, the following amounts of sludge: $267,000 \mathrm{t}$ $(64.25 \%)$ - by mono-incineration of sludge, or coincineration with other conventional fuels or biomass; 147 400 t $(35,45 \%)$ - by co-processing in cement factories; 1,200 t $(0,3 \%)$-from composting [11].

In Romania, the sludge is stored in the treatment plants $(91 \%)$, discharged to the landfill (9\%), used in agriculture (0.2\%) [11].

Considering the amounts of sludge from urban wastewater treatment plants existing in 2007, approx. 172,529 tonnes of dry matter per year, it is estimated, according to the National River Basin Management Plan in Romania, that in 2018 it will reach 520,850 tonnes of dry matter per year (Figure 3).

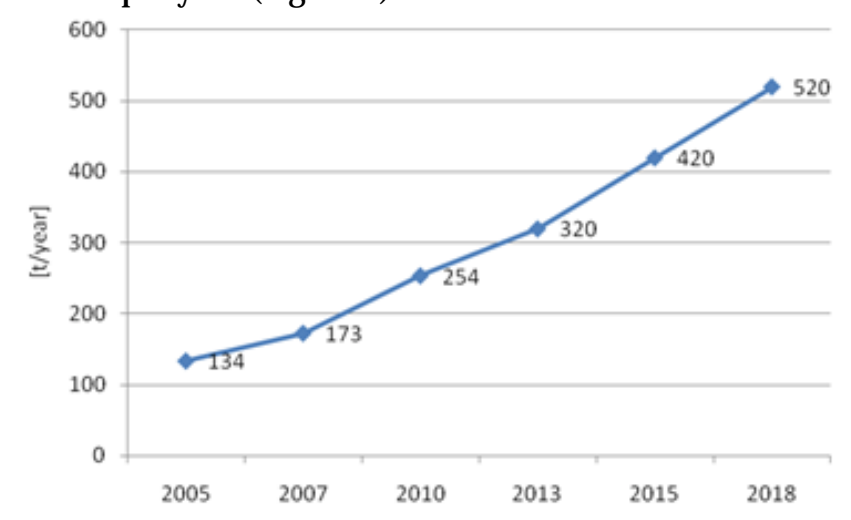

Fig. 3 Evolution of sludge generated by sewage treatment plants in Romania [8]

\section{Conclusions}

This paper describes the technologies for treating treated sludge. These technologies are biology-based technologies (advanced anaerobic digestion strategies and bio-drying) and heat-based technologies (gasification, pyrolysis and supercritical water processing).

Energy recovery of sludge from municipal wastewater treatment plants must be a technological priority that benefits the environment and reduces final wastewater and sludge treatment costs, reduces the amount of waste resulting from dehydration to ash, and also reduces transport costs and storage.

The use of sludge in agriculture to recover degraded landfills (dumps, phosphogypsum and oil-contaminated land) ensures their rapid restoration, fertility through organic matter intake.

\section{References}

1. *** THE DECISION no. 856 of 16 August 2002 on waste management records and the approval of the list of wastes, including hazardous wastes.

2. STOICESCU, A., Ecoterra, no. 28, 169, 2011.

3. RUSANESCU, C. O., RUSANESCU, M., JINESCU, C., PARASCHIV, G., Rev.Chim.(Bucharest), 70, no. 4, 2019, p. 1187-1191.

4. NEGULESCU M., Wastewater treatment of municipalities, 1978.

5. GHERMEC, O., GHERMEC, C., DUBOVAN, S., RUSANESCU, C. 0. Environmental Engineering and Management Journal, 12, 10, 2013, p.2019-2023.

6. NES, A. M., CRISAN, O. A., ORBAN, M., LAKATOS, E. S. XVIIth International Conference - Multidisciplinary Conference Professor Dorin Pavel - Founder of Romanian Hydro Power Engineering 2017.

7. ROJANSCHI, V., OGNEAN, TH., Operator's book from wastewater treatment plants, 1997.

8. KULCZYCKA, M., J., HENCLIK, A., GORAZDA, K., \& WZOREK, Z., J ournal of Cleaner Production, 95, 2015, p. 45-54.

9. NEAMT, I., IONEL, I., VLAICU, I., AGIR Bulletin, Supplement 1, 2013, p. 34-37.

10. PRICOP, F., CHIVOIU, A., JIANU, R., MOGA, I. C. AGIR bulletin no. 3/ 2017, p. 50-54.

11. *** General direction AM POS Environment, Consultant: Consortium led by Mott MacDonald Limited UK, in association with ISPE, UTCB, BIOTEHNOL, Elaboration of the national sludge management policy. National Sludge Management Strategy, Part III, Bucharest, Romania, February 2012.

12. BERKESY, C., BERKESY, L., GAVRILOAIE, C., SOMESAN, M., Study on the possibilities of capitalizing on the sludge from the urban waste water treatment plants, nr. 20, and VI, 2009.

13. DESPA, V., ANGHELINA, F. V., IANCU, D., RUSANESCU, C. O., JOURNAL OF SCIENCE AND ARTS, YEAR 17, 4, 41, 2017, p. 839-852.

14. NEGULESCU C.A.L, Processing and utilization of sludge from urban, industrial and zootechnical wastewater treatment, 2006.

15. RUSANESCU C.O., POPESCU I. N., DAVID L., $3^{\text {rd }}$ International Conference on Environmental and geological science and Engineering (EG' 10), 2010, p. 175-180.

16. SOHACIU, M. G., NICOLAE, A., GRADINARU, C., NICOLAE, M., U.P.B. Sci. Bull., Series B, Vol. 80, Iss. 4, 2018, p.219.

17. RUSÃNESCU, M., PURCAREA, A. A., RUSANESCU, C.O., Conference: $6^{\text {th }}$ International Conference on Management and Industrial Engineering - ICMIE, 2013, p.395-400.

18. SADECKA, Z., WEISS, E., MYSZOGRAJ , S., Environment Protection Engineering, Vol. 38 No. 3, 2012, p. 97-105.

19. MIDILLI A., DOGRU M., HOWARTH C. R., LING M. J . AND AYHAN T. Energy Conversion and Management, 42, 2001, p.157-172.

20. AZNAR M., MANYA J. J., GARCIA G., SANCHEZ J. L. AND MURILLO $M$. B. Influence of freeboard temperature, fluidization velocity and particle size on tar production and composition during the air gasification of sewage sludge. Energy \& Fuels, 22, 2008, p.2840-2850. 21. BERMEJ O, M. D., COCERO M. J., AIChE Journal, 52(11), 2006, p. 3933-3951.

22. RUSANESCU, C. O., MURAD, E., JINESCU, C., RUSANESCU, M., Rev. Chim.(Bucharest), 69, no. 8, 2018, p 2197-2202.

23. RADUCANU M. D., NEDEFF V., BARSAN N., CHITIMUS A. D., MOSNEGUTU E. F., Theoretical studies regarding to disposal and utilization of the sew age sludge from municipal wastew ater treatment plants. Proceedings of the Energy Efficiency and Agricultural Engineering Conference, University of Ruse Angel Kanchev, Ruse, Bulgaria, 2013, p. 356-369. 
24. SOHACIU, M., NICOLAE, A., PREDESCU, CR., VELICU, S., CALEA, $\mathrm{GH}$., Environmental Engineering and Management J ournal, 8, 4, 2009, p. 997-1001.

25. CORABIERU, A., VELICU, S., CORABIERU, P., SOHACIU, M.,Rev. Chim. (Bucharest), 70, no. 2, 2019, p. 470-474.

26. *** ORDER no. 344 of August 16, 2004 for the approval of the Technical Norms regarding the protection of the environment and especially of the soils, when using sewage sludge in agriculture.

27. RUSANESCU, C. O., JINESCU, C., RUSANESCU, M., BEGEA, M., GHERMEC, O.Rev. Chim. (Bucharest), 69, no. 1, 2018, p. 105-111.

28. RUSANESCU, C.O., RUSANESCU, M, IORDANESCU, T., ANGHELINA, F.V., J ournal of optoelectronics and advanced materials, Vol. 15, No. 7-8, 2013, p. 718-723.
29. ANDREI, V.A, MALINOVSCHI, V., RADULESCU, C., IONITA, I., TOROK, G., COACA, E., MARIN, A. H., JOURNAL OF SCIENCE AND ARTS, Issue: 1, 2019, p. 185-194.

30. RODICA, L., DULAMA, I. D., RADULESCU, C., BUCURICA, I. A., STIRBESCU, R. M., TEODORESCU, S., J ournal of Science and Arts , Year 18, No. 4(45), 2018, p. 1033-1044.

31. POPESCU, I. N., ZAMFIR, S., ANGHELINA, V.F., RUSANESCU, C.O., MEQAPS'10, 2010, p.200-205.

32. RUSANESCU, C. O., RUSANESCU, M., ANGHELINA, F. V., J. Optoelectron. Adv. Mater. 15, 7-8, 2013, p.724-729.

33. MURARESCU, O., PEHOIU, G., RADULESCU, C., DULAMA, I.D., TEODORESCU, S., STIRBESCU, R. M., MURATOREANU, G., Rev. Chim.(Bucharest), 69, no. 5, 2018, p.1037-1040.

Manuscript received: 22.03 .2019 